individual and team in order to master the heritage of universal and national culture, implementation of social values and development of positive qualities. Training in the implementation of socio-pedagogical activities in educational institutions helps future professionals to understand their belonging to a community that has its own traditions and cultural characteristics, provides socialization and personal fulfillment. The study is based on the socio-cultural paradigm of education, as the main in determining the socio-pedagogical professional trajectory of biology teachers and the basics of health

Key words: socio-pedagogical activity, teacher of biology and basics of health, secondary education institutions

Стаття надійшла до редакції 16.03.2021 р.

DOI: https://doi.org/10.33989/2075-146x.2021.27.247102

УДК 379.81:614-053.81

\title{
ВІТАЛІЯ МИРОШНИЧЕНКО
}

ORCID: 000-0003-2425-4163

Полтавський національний педагогічний університет імені В. Г. Короленка

\section{СУЧАСНИЙ СТАН РОЗВИТКУ СИСТЕМИ ЗАКЛАДІВ ОЗДОРОВЛЕННЯ ТА ВІДПОЧИНКУ ДЛЯ МОЛОДІ В УКРАЇНІ}

\begin{abstract}
У статі обгрунтовано стан розвитку системи закладів оздоровлення та відпочинку в Україні. Охарактеризовано нормативну базу їх функціонування, акцентовано стратегію розвитку галузі, види та форми діяльності. Висвітлено мету, завдання, напрями роботи громадських організацій. Розкриті підходи до класифікації типів закладів. Визначені особливості роботи різних типів закладів.
\end{abstract}

Ключові слова: дитячий заклад оздоровлення та відпочинку, нормативні документи, система, типи закладів оздоровлення та відпочинку

Постановка проблеми та її зв'язок із важливими науковими та практичними завданнями. В умовах модернізації українського суспільства освіта як транслятор норм і цінностей буття втрачає свої духовноморальні орієнтири. В умовах інформаційного суспільства спостерігаємо формування нового типу інтелекту, зміни інформаційно-технічної реальності, прагматичне мислення у всіх сферах життя, нехтування гуманітарним основами життєдіяльності людської спільноти. Важливою стратегією функціонування освіти як інституції має стати підготовка дитини до життя в швидкозмінних реаліях на основі гуманістичних підходів, де людина $є$ головною цінністю. Тому пошук нових шляхів і способів адаптації дитини до таких змін, створення умов для нових можливостей розвитку людини і розвитку самої системи освіти має стати пріоритетним у сучасному просторі.

Літній період в освіті - канікули, які тривають досить великий проміжок часу. Його організація у кожній родині відбувається по-різному. Значна частина дітей перебуває у дитячих закладах оздоровлення та відпочинку, специфіка функціонування яких передбачає знаходження у тимчасовому дитячому колективі, зміну оточення, дотримання певних правил, тобто ми говоримо про змінні реалії, у яких дитина має навчитися швидко реагувати на виклики, події, уміти вирішувати поставлені завдання.

Важливим є усвідомлення системи функціонування закладів оздоровлення та відпочинку в Україні та можливості їі використання у становленні особистості.

Аналіз останніх досліджень і публікацій. Дитячий заклад оздоровлення та відпочинку (ДЗОВ) як позашкільний заклад є важливим складником функціонування системи оздоровлення та відпочинку в Україні. Теоретико-методологічні засади позашкільної освіти, питання організації діяльності учнів та функціонування цих закладів стали предметом досліджень І. Андрухів, О. Бартків, В. Гогулинського, А. Калініченко, О. Кольцової, Г. Пустовіт, Р. Расевич, Т. Ромм І. Старобудцевої, О. Сухомлинської, Т. Сущенко, О. Тисовського, Г. Шутки, І. Фрішман та ін. У ряді дисертаційних робіт висвітлюються різні аспекти функціонування системи цих закладів, зокрема М. Наказний розглядає питання проектування діяльності дитячого закладу оздоровлення та відпочинку; Я. Кашуба - формування системи дитячого оздоровлення i туризму; Т. Блистів, А. Гакман, П. Рибалко - організаційного та методичного забезпечення рекреаційнооздоровчої діяльності у закладі; Н. Олексієнко - розвитку освітньо-виховної роботи у дитячих оздоровчих таборах східного регіону України.

Мета статті - розкрити стан системи закладів оздоровлення та відпочинку в Україні.

Виклад основного матеріалу дослідження. Реалізація положень позашкільної освіти здійснюється через розгалужену систему закладів позашкільної освіти, які в Україні представлені досить широко. Зазначимо, що 
діяльність дитячих закладів оздоровлення та відпочинку в Україні регламентується відповідними державними нормативними документами:

- Конвенція ООН про права дитини (Конвенція про права дитини... );

- закон України «Про охорону дитинства» (Закон Украӥни «Про охорону дитинства»..., 2001);

- закон України «Про позашкільну освіту» (Закон Украӥни «Про позашкільну освіту»..., 2005);

- закон України «Про оздоровлення та відпочинок дітей» (Закон України «Про оздоровлення та відпочинок дітей»..., 2008).

Водночас Державна національна програма «Освіта» («Україна XXI століття») (Державна національна програма «Освіта», 1994) та Загальнодержавна соціальна програма «Національний план дій щодо реалізації Конвенції ООН про права дитини» на період до 2021 року» (Державна соціальна програма «Національний ..., 2018) визначають стратегічні завдання, які стоять перед українською освітою. Постанова Кабінету міністрів «Про організаційне і фінансове забезпечення відпочинку та оздоровлення дітей в Україні» (Постанова Кабінету Міністрів Украӥни «Про організаційне...), Типове положення про дитячий заклад оздоровлення та відпочинку регламентують різні напрями функціонування таких закладів (Типове положення про дитячий заклад ...).

Конкретизуємо це. Конвенція ООН про права дитини проголошує, що держави-сторони поважають і заохочують право дитини на всебічну участь у культурному і творчому житті та сприяють наданню ій відповідних і рівних можливостей для культурної і творчої діяльності, дозвілля і відпочинку. У статті 31 визначається право дитини на відпочинок і дозвілля, право брати участь в іграх і розважальних заходах, що відповідають їі віку, та вільно брати участь у культурному житті та займатися мистецтвом (Конвенція про права дитини... ). У Законі України «Про охорону дитинства» стратегічним загальнонаціональним пріоритетом визначається охорона дитинства і з метою забезпечення реалізації прав дитини на життя, охорону здоров'я, освіту, соціальний захист і всебічний розвиток встановлюються основні засади державної політики у цій сфері (Закон України «Про охорону дитинства»..., 2001).

Закон України «Про позашкільну освіту визначає державну політику у сфері позашкільної освіти, іiі правові, соціально-економічні, а також організаційні, освітні та виховні засади. Зокрема у статті 6 проголошується, що вихованці, учні мають право на здобуття позашкільної освіти відповідно до їх здібностей, обдарувань, уподобань та інтересів на принципі добровільності вибору типів закладів та видів діяльності. Цей процес здійснюється за участю батьків або осіб, які їх замінюють, трудових колективів, громадських організацій, товариств, фондів. Основними напрямами позашкільної освіти визначаються художньоестетичний, туристсько-краєзнавчий, еколого-натуралістичний, науково-технічний, дослідницькоекспериментальний, фізкультурно-спортивний, військово-патріотичний, бібліотечно-бібліографічний, соціально-реабілітаційний, оздоровчий та гуманітарний (Закон України «Про позашкільну освіту»..., 2005).

Основні засади державної політики у сфері оздоровлення та відпочинку дітей, повноваження органів виконавчої влади і органів місцевого самоврядування, правові, фінансові та організаційні засади утворення $\mathrm{i}$ діяльності дитячих закладів оздоровлення та відпочинку, права, обов\&ароs;язки та відповідальність усіх учасників процесу висвітлені у Законі України «Про оздоровлення та відпочинок дітей». У ньому зазначено, що державна політика у сфері оздоровлення та відпочинку дітей грунтується на принципах рівності прав кожної дитини на оздоровлення та відпочинок; здійсненні заходів, спрямованих на зміцнення здоров\&ароs;я дітей шляхом організації оздоровлення та відпочинку; створенні оптимальних умов для безпечного та ефективного перебування дітей у дитячих закладах оздоровлення та відпочинку; створенні умов для зміцнення фізичного та психічного здоров\&аpos;я дітей шляхом належної організації оздоровлення та відпочинку; наданні послуг 3 оздоровлення та відпочинку дітям, які потребують особливої соціальної уваги та підтримки; адресності соціальної допомоги, що надається з державного і місцевих бюджетів для оздоровлення та відпочинку дітей (Закон Украӥни «Про оздоровлення та відпочинок дітей»..., 2008).

Державна національна програма «Освіта» («Україна ХХІ століття») проголошує стратегію розвитку освіти в Україні на найближчі роки та перспективу XXI століття; пріоритетні напрями реформування освіти; основні шляхи реформування освіти; принципи реалізації Програми; зміст освіти; шляхи реформування змісту загальноосвітньої та фахової підготовки; позашкільне навчання та виховання; шляхи реформування позашкільного навчання і виховання. Визначено, що одним із основних напрямів позашкільної освіти $\epsilon$ оздоровчий, який забезпечує необхідні умови для змістовного відпочинку та передбачає оволодіння вихованцями знаннями про здоровий спосіб життя, організацію їх оздоровлення, набуття і закріплення навичок, зміцнення особистого здоров\&ароs;я і формування гігієнічної культури особистості (Державна національна програма «Освіта», 1994). Ще один документ регламентує організаційно-правові засади діяльності та порядок прийому дітей до дитячого закладу; організацію оздоровчо-виховного процесу та процесу відпочинку; харчування та медичне обслуговування, управління та кадрове забезпечення; фінансово-господарську діяльність та матеріально-технічну базу, державний контроль за діяльністю дитячих закладів; міжнародне співробітництво. Це Типове положення про дитячий заклад оздоровлення та (Типове положення про дитячий заклад ...). 
Аналіз зазначених нормативних документів дає підстави зробити висновок, що вони проголошують основи державної політики щодо відпочинку та оздоровлення молоді; регламентують організаційні, фінансові, методичні аспекти реалізації державних програм; визначають відповідальність і обов'язки тих, хто забезпечує цей процес.

Важливим складником системи оздоровлення та відпочинку дітей України є сформовані останнім часом громадські, неурядові організації, зокрема Асоціації, Співдружності та інші об'єднання, які покликані вирішувати проблеми функціонування дитячих закладів оздоровлення та відпочинку. Свої завдання вони вбачають в:

- участі у формуванні законодавчої бази у сфері організації дитячого відпочинку та оздоровлення;

- пошук нових форм розвитку дитячих закладів оздоровлення та відпочинку в сучасних економічних умовах;

- сприяння дитячим закладам оздоровлення та відпочинку у питаннях правового та медичного захисту,

- сприяння інформованості суспільства (батьків, освітніх, медичних, культурних закладів ) щодо стратегії і тактики функціонування дитячих закладів оздоровлення та відпочинку;

- сприяння дитячим закладам оздоровлення та відпочинку у питаннях психолого-педагогічного, методичного забезпечення шляхом індивідуального та групового консультування, проведення зборів учасників літнього руху, презентацій результатів роботи кращих дитячих закладів оздоровлення та відпочинку, обговорення нагальних питань на семінарах, симпозіумах, конференціях тощо.

3-поміж них вирізняється Всеукраїнська благодійна організація «Асоціація за нове покоління «Лелека (1999 р.)», мета якої - спільна діяльність іiі членів для надання допомоги дітям у забезпеченні їх розвитку, додаткової освіти, оздоровлення, змістовного дозвілля, сприяння розбудові дитячих оздоровчих закладів розвитку, професійного спілкування, безпечного та яскравого літа для Дитини [https://www.facebook.com > LelekaVBO]. До iï складу входять власники та керівники дитячих оздоровчих закладів, вожаті, вихователі, педагоги, психологи, керівники педагогічних програм та аніматори. Асоціація співпрацює з Міністерством соціальної політики України, Управліннями освіти, центрами соціальних служб для сім’і, дітей та молоді облдержадміністрацій, обласними радами професійних спілок, благодійними фондами, громадськими організаціями, педагогічними виданнями України. Напрямами діяльності Асоціації є проведення громадської експертизи нормативно-правових документів, що регламентують життєдіяльність галузі, спільні проекти підготовки до літнього оздоровчого сезону та конкурси-огляди дитячих закладів оздоровлення та відпочинку.

Всеукраїнська Благодійна організація «Асоціація за нове покоління «Лелека» $є$ членом Всесвітньої співдружності таборів (ICF), делегує у склад ВCТ повноважного представника від України, систематично презентує кращий досвід роботи дитячих оздоровчих закладів України в межах Всесвітньої та Свропейської Співдружності дитячих таборів. Делегації Асоціації представляли Україну на Міжнародних конференціях 3 питань оздоровлення у Кейптауні (Австралія), Кітені (Болгарія), Мехіко (Мексика), Квебеку (Канада), Тайбеї (Тайвань) [https://www.facebook.com > LelekaVBO].

У 2020 році виникає Громадська спілка «Асоціація організаторів дитячого оздоровлення, відпочинку та туризму «Люди літа», співзасновником якої є автор статі. Головною метою діяльності проголошено захист прав і свобод, задоволення суспільних, зокрема економічних, соціальних, культурних, екологічних та інших інтересів іiі членів (учасників) та інших суб'єктів у сфері дитячого відпочинку, оздоровлення, дозвілля та туристичної діяльності. У завданнях організації з'являються тези про відстоювання спільних інтересів членів спілки та суб'єктів ДЗОВ, необхідності розробки навчальної, методичної, інформаційної бази, підготовку кваліфікованих фахівців, здатних забезпечити високий рівень послуг на ринку дитячого оздоровлення та відпочинку; розробку та впровадження інноваційних технологій для внутрішнього та зовнішнього використання; розробку системи моніторингу та оцінювання роботи закладів оздоровлення та відпочинку [https://opendatabot.ua/c/43737686; https://www.facebook.com/summer.people.ua/].

Можемо констатувати, що різні аспекти оздоровлення та відпочинку дітей у дитячих закладах оздоровлення та відпочинку представлені не тільки в урядових документах. Поява різних громадських утворень свідчить про важливість цього питання для громадянського суспільства, яке пропонує власну візію таких процесів.

У Постанові Кабінету міністрів України «Про затвердження Типового положення про дитячий заклад оздоровлення та відпочинку» зазначається, що дитячий заклад оздоровлення та відпочинку - це постійно або тимчасово діючий, спеціально організований або пристосований заклад, призначений для оздоровлення, відпочинку, розвитку дітей, що має визначене місце розташування, матеріально-технічну базу, кадрове забезпечення та технології для надання послуг з оздоровлення та відпочинку дітей відповідно до державних соціальних стандартів надання послуг з оздоровлення та відпочинку. Дитячий заклад оздоровлення та відпочинку є позашкільним оздоровчо-виховним закладом, що створюється з метою реалізації права кожної дитини на повноцінний відпочинок і оздоровлення, зміцнення здоров\&аpos;я, задоволення інтересів і духовних запитів відповідно до індивідуальних потреб дітей шкільного віку (Типове положення про дитячий заклад ...).

Дитячі заклади оздоровлення та відпочинку на сьогодні розглядаються як вагома частина структури позашкільної освіти, де, зазвичай, у канікулярний період створюється можливість фізичного, інтелектуального, 
емоційного, духовного, морального розвитку дитини. За даними інтернет порталу childcamp.com.ua в Україні працює більше тисячі п\&ароs;ятисот таборів різної форми власності, тематичної спрямованості, напрямів діяльності.

За законом України «Про оздоровлення та відпочинок дітей» визначають заклади оздоровлення (дитячий заклад санаторного типу, дитячий центр - заклад, що функціонує протягом року, позаміський заклад оздоровлення та відпочинку) та відпочинку (відпочинку табір з денним перебуванням, дитячий заклад праці та відпочинку, наметове містечко) відповідно до тих функцій, які $є$ пріоритетними у їх роботі. Схарактеризуємо їх:

- дитячий заклад санаторного типу - заклад, у якому діти перебувають цілодобово і де поряд 3 оздоровчими надається комплекс медичних послуг, спрямованих на поліпшення стану їхнього здоров\&ароs;я, запобігання захворюванням. 3 урахуванням природно-кліматичних умов, наявної лікувально-оздоровчої бази, кадрового забезпечення такі заклади можуть бути спеціалізованими;

- $\quad$ дитячий центр - заклад, що функціонує протягом року, в якому діти перебувають цілодобово. Центр має відповідне кадрове забезпечення, спеціально відведену територію, матеріально-технічну базу, які відповідають санітарно-гігієнічним нормам, для організації оздоровлення, відпочинку та навчання дітей;

- позаміський заклад оздоровлення та відпочинку - заклад, що функціонує впродовж року, сезонно або під час канікул, у якому діти перебувають цілодобово. Заклад повинен мати спеціально відведену територію, що знаходиться в курортній або заміській зоні, матеріально-технічну базу, що відповідає санітарно-гігієнічним нормам, кадрове забезпечення для організації оздоровлення. Відповідний заклад також може належати до закладу відпочинку;

- $\quad$ табір з денним перебуванням - табір, тимчасово утворений у навчальному закладі, закладі культури, охорони здоров\&ароs;я, фізичної культури та спорту, в якому забезпечується належний догляд за дітьми, виховний процес, їх повноцінне дозвілля, розвиток творчих здібностей та інтересів і де діти перебувають протягом дня, але не менше 6 годин. Деякі науковці називають такі табори пришкільними і характеризують їх як самостійну адміністративну структуру при загальноосвітньому навчальному закладі, метою якого є зміцнення здоров'я, організації активного відпочинку, задоволення інтересів та духовних потреб дітей і підлітків (Настенко, 2006);

- $\quad$ дитячий заклад праці та відпочинку - заклад з денним або цілодобовим перебуванням, у якому поряд 3 відпочинком організовується трудова діяльність 3 метою формування у дітей трудових інтересів і навичок;

- $\quad$ наметове містечко - тимчасово діючий заклад з денним або цілодобовим перебуванням, облаштований на спеціально відведеній території, що відповідає санітарно-гігієнічним вимогам та нормам, у якому здійснюється комплекс заходів, спрямованих на формування у дітей навичок безпечної життєдіяльності, самообслуговування, колективізму.

Інший підхід пропонує А. Калініченко (Калініченко), який на підставі нормативно-правової бази надає змогу здійснити класифікацію існуючих типів дитячих закладів оздоровлення та відпочинку, відповідно до встановлених ознак:

• за організаційно-правовою формою: некомерційні та комерційні організації; відомчі; муніципальні;

- за формою власності: державна, комунальна, приватна;

- за видами діяльності: заміські стаціонарні; оздоровчі з денним перебуванням на період канікул; дитячі санаторії; санаторно-оздоровчі цілорічної дії; праці та відпочинку; палаточні та ін.;

- за часом дії: заміські стаціонарні цілорічні; заміські стаціонарні літні; тимчасові на базі санаторіїв, баз відпочинку, закладів освіти; заміські нестаціонарні літні;

- за специфікою призначення: спеціалізовані профільні табори (інтелектуального розвитку, соціальної адаптації, військово-спортивно-оздоровчих, еколого-біологічних, художньої та технічної творчості.

Останнім часом величезний сегмент ринку України представлений проєктними таборами, які працюють у форматі дитячих виїзних туристичних груп або педагогічних команд. Основою їх існування є цікаві програми, які обирають для себе діти та батьки. Такі заклади не мають власної матеріально-технічної бази і користуються послугами пансіонатів, баз відпочинку, готелів. Це можуть бути бази не тільки в Україні, але й за їі межами. До прикладу Міжнародний творчий дитячий табір «Час Індиго».

Висновки. Проведений аналіз системи оздоровлення та і відпочинку дає підстави стверджувати, що на сьогодні в Україні існує достатньо розгалужена система таких закладів, які мають певні часові рамки свого функціонування (протягом календарного року, у літній період), різні бази існування (у закладах загальної середньої освіти, в установах додаткової освіти, у медичних, оздоровчих центрах, базах і комплексах), різний профіль (оздоровлення, відпочинок, освіта). Нормативні документи законодавчо регламентують їх організаційну, фінансову, освітню, культурну діяльність, висвітлюють принципи та напрями роботи. Останнім часом до цієї роботи активно стали долучатися громадські організації, які оперативно реагують на виклики сьогодення. 


\section{Список використаних джерел}

Державна національна програма «Освіта». («Украӥна ХХІ століття»). (1994). Київ: Райдуга.

Державна соціальна програма «Національний план дій щзодо реалізації Конвенції ООН про права дитини» на період до 2021року: 30 травня 2018 року. Взято з https://www.kmu.gov.ua/ua/npas/pro-zatverdzhennyaderzhavnoyi-socialnoyi-programi-nacionalnij-plan-dij-shodo-realizaciyi-konvenciyi-oon-pro-prava-ditini-naperiod-do-2021-roku

Закон Украӥни «Про охорону дитинства»: прийнято 26 квіт. 2001 р. № 2402-III. Взято 3 http://uaua.info/content/articles/4061.html

Закон України «Про позашкільну освіту»: № 1841-III зі змінами від 06.06 .2005 р. Взято 3 http://www.osvita.org.ua/pravo/law_03/.

Закон України «Про оздоровлення та відпочинок дітей». (2008). Голос України, 204. Взято 3 http://zakon.nau.ua/doc/?code=375-17

Калініченко, А. До понятійно-категоріальної визначеності дефініцій системи дитячого оздоровлення та відпочинку. Взято з irbis-nbuv.gov.ua > cgi-bin > opac > search > apd

Конвенція про права дитини. (1995). Київ: Українська правнича фундація: Право.

Настенко, Н. В., Каліберда, Г. А., Халецька, Л. Л., Сліпак, В. О. (2006). Барви сонячного літа: навч. метод. посіб. [для директорів літніх таборів, вожатих, вихователів, інструкторів з фізкультури і спорту, плавання та педагогів-організаторів літнього відпочинку]. Полтава: ПОІППО, 2006.

Постанова Кабінету Міністрів Украйни «Про організачійне $і$ фінансове забезпечення відпочинку та оздоровлення дітей в Україні». Взято з http://zakon4.rada.gov.ua/laws/show/323-97-\%D0\%BF

Типове положення про дитячий заклад оздоровлення та відпочинку. Взято 3 https://zakon.rada.gov.ua/laws/show/422-2009-\%D0\%BF\#Text

https://www.facebook.com > LelekaVBO

https://opendatabot.ua/c/43737686

https://www.facebook.com/summer.people.ua/

https://xn-80aagahqwyibe8an.com/zakon-ukrajiny/stattya-tipi-dityachih-zakladiv-ozdorovlennya-56790.html

\section{References}

Derzhavna natsionalna prohrama “Osvita” ("Ukraina XXI stolittia”) [State National Program "Education". ("Ukraine of the XXI century")]. (1994). Kyiv: Raiduha [in Ukrainian].

Derzhavna sotsialna prohrama «Natsionalnyi plan dii shchodo realizatsii Konventsii OON pro prava dytyny» na period do 2021 roku [State Social Program "National Action Plan for the Implementation of the UN Convention on the Rights of the Child" until 2021]: 30 travnia 2018 roku. Retrieved from https://www.kmu.gov.ua/ua/npas/pro-zatverdzhennya-derzhavnoyi-socialnoyi-programi-nacionalnij-plan-dijshodo-realizaciyi-konvenciyi-oon-pro-prava-ditini-na-period-do-2021-roku [in Ukrainian].

Kalinichenko, A. Do poniatiino-katehorialnoi vyznachenosti definitsii systemy dytiachoho ozdorovlennia ta vidpochynku [To the conceptual and categorical definiteness of the definitions of the system of children's health and recreation]. Retrieved from $\mathrm{z}$ irbis-nbuv.gov.ua > cgi-bin > opac > search > apd [in Ukrainian].

Konventsiia pro prava dytyny [Convention on the Rights of the Child]. (1995). Kyiv: Ukrainska pravnycha fundatsiia: Pravo [in Ukrainian].

Nastenko N. V., Kaliberda H. A., Khaletska L. L., \& Slipak V. O. (2006). Barvy soniachnoho lita [Colors of sunny summer]: navch. metod. posib. [dlia dyrektoriv litnikh taboriv, vozhatykh, vykhovateliv, instruktoriv $\mathrm{z}$ fizkultury i sportu, plavannia ta pedahohiv-orhanizatoriv litnoho vidpochynku]. Poltava: POIPPO [in Ukrainian].

Postanova Kabinetu Ministriv Ukrainy «Pro orhanizatsiine i finansove zabezpechennia vidpochynku ta ozdorovlennia ditei $v$ Ukraini» [Resolution of the Cabinet of Ministers of Ukraine "On organizational and financial support of recreation and rehabilitation of children in Ukraine"]. Retrieved from http://zakon4.rada.gov.ua/laws/show/323-97-\%D0\%BF [in Ukrainian].

Typove polozhennia pro dytiachyi zaklad ozdorovlennia ta vidpochynku [A typical provision for a children's health and recreation facility]. Retrieved from https://zakon.rada.gov.ua/laws/show/422-2009-\%D0\%BF\#Text [in Ukrainian].

Zakon Ukrainy «Pro okhoronu dytynstva» [Law of Ukraine "On Child Protection"]: pryiniato 26 kvit. 2001 r. № $2402-$ III. Retrieved from http://uaua.info/content/articles/4061.html [in Ukrainian]. 
Zakon Ukrainy «Pro pozashkilnu osvitu» [Law of Ukraine "On Extracurricular Education"]: № 1841-III zi zminamy vid 06.06.2005 r. Retrieved from http://www.osvita.org.ua/pravo/law_03/ [in Ukrainian].

Zakon Ukrainy «Pro ozdorovlennia ta vidpochynok ditei» [Law of Ukraine "On rehabilitation and recreation of children"]. (2008). Holos Ukrainy [Voice of Ukraine], 204. Retrieved from http://zakon.nau.ua/doc/?code=375-17 [in Ukrainian].

https://www.facebook.com > LelekaVBO

https://opendatabot.ua/c/43737686

https://www.facebook.com/summer.people.ua/

https://xn-80aagahqwyibe8an.com/zakon-ukrajiny/stattya-tipi-dityachih-zakladiv-ozdorovlennya-56790.html

\section{MYROSHNYCHENKO V.}

Poltava V. G. Korolenko national pedagogical University, Ukraine

\section{CURRENT STATE OF THE SYSTEM OF CHILDREN'S HEALTHCARE AND LEISURE INSTITUTIONS DEVELOPMENT IN UKRAINE}

The paper substantiates the state of the system of children's healthcare and leisure institutions development in Ukraine. We can state that today there is a fairly extensive system of institutions that have a certain time frame of functioning (during the calendar year, in the summer), different bases of existence (in general secondary educational institutions, in additional educational institutions, in medical and health centers, bases and complexes, tourist centers), and different profile (healthcare, leisure, education).

The regulative base of the institutions functioning is characterized. The strategy of branch development, types and forms of activity, principles and directions of work are emphasized. Documents legally regulate their organizational, financial, educational, and cultural components.

The aim, objectives, directions of public organizations work are covered. The main aim of the public organizations activities in the field of children's healthcare and leisure institutions is the protection of rights and freedoms, the satisfaction of public, including children's economic, social, cultural, environmental and other interests. Objectives of organizations include the following ones: defending the rights and freedoms of the process participants, the need to develop educational, methodological, information base, and training of qualified professionals capable of providing a high level of services in the sphere of children's healthcare and leisure; the development and implementation of innovative technologies for internal and external use; and the development of a system for monitoring and evaluating the work of healthcare and leisure institutions.

Approaches to the classification of types of institutions are revealed. Features of work of different types of institutions are defined.

Keywords: children's healthcare and leisure institution, regulative documents, system, types of healthcare and leisure institutions

Стаття надійшла до редакції 02.04.2021 р. 